\title{
10. De Genesi ad litteram 8: On Divine Communication and Providence
}

\author{
Anthony Dupont
}

\section{Introduction}

Book Eight of Augustine's De Genesi ad litteram is not easily summarized, mainly because it presents a thematic potpourri. It touches upon many questions the bishop of Hippo answers more elaborately in other chapters of his literal exegesis of the creation account. To name only a few examples: while the methodological debate about the literal or figurative exegesis of Genesis is dealt with extensively in Book 1 , the specific question in Book 8 whether to consider Paradise in a literal or non-literal sense ${ }^{1}$ was already introduced in Book $6 ;^{2}$ in a different context, the issue of divine providence which is elaborated in Book 8 was under consideration in Book $5 ;^{3}$ Augustine's exposition in book 8 on the interaction between the human body and soul is linked with many other expositions in De Genesi ad litteram about the soul - at the very end of Book 7, in which he discussed the issues of the possible pre-existence of the soul and its relation to the body, he warns not to make rash assertions about the human soul, Book 10 discusses the soul's origin; Book 9 returns to the diverse ways of God's communication and double predestination already thematized in Book 8, while Book 12 expounds on visions (where Paradise now is not the garden in Eden, but sublimated to the heavenly Paradise - the third Pauline heaven); Augustine's exposition in Book 8 on the tree of knowledge of good and evil evidently precludes his statements about the fall, original sin and carnal concupiscence in Books 10-11. Admittedly, De Genesi ad litteram presents a Gordian knot, and is a clear example of Augustine's associative way of reasoning and reading Scripture.

Our presentation of De Genesi ad litteram 8 has two objectives. First, a tour d'horizon of this book is offered, in order to grasp the general structure of Augustine's exegesis of Genesis 2,8-17, describing Paradise, and the main flow of ideas this biblical passage introduces in Augustine's mindset. As Augustine is a contextualized thinker, it is quintessential to present his thoughts always

1 Augustinus, Gn. litt. 8,1,1-3,6 (CSEL 28,1, 229,1-234,23 Zycha).

2 Augustinus, Gn. litt. 6,23,34 (196,1-12 Z.).

3 Augustinus, Gn. litt. 5,20,41-21,42 (164,13-166,6 Z.). 
in their broader textual context. Secondly, the four most developed arguments of this book will be discussed. These four, more or less, stand on their own in this book, and as such, play an important role in the development of certain aspects of Augustine's thinking beyond De Genesi ad litteram, and thereby aptly illustrate certain evolutions therein: the so-called literality of his Bible reading, the eternal problem of Theodicy, God's communication in the history of mankind, and the functioning of divine providence.

\section{Outline of De Genesi ad litteram 8}

The general framework of the eighth book is determined by the description of how God planted Paradise in Eden, the subsequent description of the trees and four rivers of Paradise, next, a consideration of mankind's activities there, ending with the commandment not to eat from the tree of knowledge of good and evil, this is Genesis 2,8-17.

The statement plantauit Dominus Deus paradisum in Eden in Genesis 2,8 prompts Augustine to explain that there are three ways to consider Paradise in particular, and the Genesis account more generally: first, corporaliter on a literal, material, historical level; second, spiritualiter - conceiving of it solely in a spiritual or figurative sense; third, utroque modo - combining both approaches, understanding Paradise literally and, additionally and differently, also spiritually. Augustine starts a lengthy exposition on these three modes of Bible exegesis, and expresses his preference for the third method: allegorical exegesis which does not exclude a literal reading. He argues that the book of Genesis, although it could and should be understood as containing allegorical prophecies, first of all should be understood as a historical book. Hence he pleads, at length, for a literal rendering of the creation account: as Adam was literally created, in the same literal/material/historical way should be taken: God planted Paradise, the trees (including the so-called tree of life and the tree of discerning good and evil) and the rivers it contains. Paradise was a historical reality.

Talking about Genesis 2,9 - God's production of trees out of the earth -, Augustine takes care to clarify that this statement does not contradict Genesis 1,11-12, stating that God created all trees on the third creation day, and Genesis 1,29, when God offered all trees as sources of food to mankind on the sixth day. God's production of trees in Paradise in Genesis 2 is the completion of the potentiality of all trees God created in Genesis 1. Augustine's commentary on Genesis 2,10-14 - the planting of Paradise, its trees and rivers -, thus concentrates on the three possible exegetical methods, and on his plea not to 
neglect the historical character of Genesis. His analysis of the tree of knowledge of good and evil - not as a bad tree as such, but referring to man's transgression of the divine commandment - is announced, but postponed.

Next, Augustine turns to Genesis 2,15: mankind's working (operari) and guarding (custodire).

Working Paradise. Since the fall had not yet condemned man to hard labor as punishment for original sin, Augustine here describes agriculture in Paradise as delightful: agricultura non laboriosa sed deliciosa. ${ }^{4}$ One of these pre-lapsarian delights of agriculture is that the latter attunes human reason with nature. Augustine sees a similar attunement on a cosmic scale, namely in the double-functioning of divine providence - a topic he introduces at this juncture, but waits to elaborate it.

Guarding Paradise. Augustine seems to think that the statement of Genesis 2,15 ut custodiret - to guard paradise -, is somewhat obscure. He expounds three possible exegetical explanations - they are quite lengthy, and we will present them only succinctly. First, as mankind is working in Paradise, he should likewise be guarding in Paradise - and Augustine here suggests that guarding is a figurative translation of working. Man should interiorize the fruits of his labor by discipline, he should harvest obedience. Second, guarding against, perhaps - Augustine mentions this, but is not conclusive - literally guarding against wild animals, but more significantly, on a symbolic level, guarding against everything which would result in mankind's expulsion from this delightful Paradise. Augustine's third exegesis is, on a syntactical level, somewhat a stretch. Departing from the observation that Genesis 2,8 is the first time the Bible addresses God as Dominus Deus - previously only Deus was mentioned - Augustine proposes to consider God as the grammatical subject of the verbs operari and custodire. As a side note, in the Vulgate, Dominus Deus is already mentioned at Genesis 2,4, but Augustine reads the Vetus Latina. Purely on the basis of grammar, his statement that Deus Dominus is the subject of the two verbs is not incorrect, and thus would signify that God both works and guards mankind. Augustine subsequently - again while elucidating the twin operation of God's providence - reflects upon God's constant and permanent grace after and beyond man's creation. The same God who created man works and guards him so he could remain good and blessed. The underlying thesis that God's creational grace thus does not suffice to live a good life, and that man is always in need of God's additional grace, for some scholars, would be a significant indication of the continuity of Augustine's doctrine of grace. Other scholars probably would argue that Augustine inserted this passage

4 Augustinus, Gn. litt. 8,10,22 (246,27-247,9 Z.). 
about the third reading of ut custodiret, with God as its graceful acting subject, at a later stage, after the outburst of the Pelagian controversy - as suggested by Paul Agaësse and Aimé Solignac in their comprehensive notes complémentaires. ${ }^{5}$ Purely on the basis of the content, it is difficult to substantiate whether this passage is a later insertion, and such a conclusion would require an in depth philological analysis. Noteworthy however is that this alternative exegesis is a hapax legomenon in Augustine's oeuvre. In the circa 10 times he quotes and comments this verse, he never repeats his claim that God is the grammatical subject of "working and guarding," not even in his Contra Iulianum opus imperfectum 6,2 , where such a stress on grace would not be abnormal. A similar exegetical approach is likewise not to be found in contemporary patristic literature - for instance, Ambrose, Jerome, Gregory - at least as far as the digital tools allow us to notice. Augustine's exegetical hapax however did not disappear. Bede the Venerable quoted this passage from De Genesi ad litteram in his own commentary on Genesis, ${ }^{6}$ which was also the case for Hrabanus Maurus, ${ }^{7}$ probably through the mediation of Bede.

Genesis 2,16-17 is well known by all Jewish, Christian and, mutatis mutandis Muslim (Qu'ran 7,19-24) exegetes and theologians: the divine commandment not to take a bite of the lignum scientiae boni et mali. Augustine intends to meticulously explain the second adjective: why mali? First of all, in an antiManichaean reflex, he stresses that the tree as such was not evil by nature, it did not have poisonous fruits - God has created everything good. Second, and more importantly, the said tree offered knowledge to discern evil from good because, by instituting a commandment, it offers the possibility of the latter's transgression, which thus is evil - disobedience.

The remainder of Book Eight is devoted to two interrelated topics: God's speaking and his providence. The divine prohibition to eat from the Paradise tree in Genesis 2,16-17 causes Augustine to reflect upon the way God uttered that embargo to Adam. Augustine introduces this question quite concisely at this juncture, subsequently he extensively and systematically covers the twofold operation of divine providence, and finally he ends the Eighth Book by returning to the question of how God communicated with Adam. These two issues are studied more comprehensively in the second part of this contribution.

5 Paul Agaësse and Aimé Solignac (edd.), La Genèse au sens littéral en douze livres (VIII-XII) (Bibliothèque Augustinienne: Exégèse 7: 49; Paris, 1972), 505.

6 Beda Venerabilis, In Genesim 1,2,15 (CCSL 118A, 51,1612-1623 Jones).

7 Hrabanus Maurus, Commentaria in Genesim 1,12 (PL 107:480). 


\section{Four 'how's}

Augustine intends, grosso modo, to answer four central questions for his readers in Book 8, more or less in the order of their textual occurrence: how ,literal ${ }^{6}$ are literal Bible hermeneutics, how do we have to conceive of evil, how does God speak, how does divine providence operate?

\subsection{First how: Ad litteram?}

Our general exploration of Book 8 started with Augustine's plea for a double hermeneutics of the Paradise account, namely figuratively and literally, and his warning never to forget its literal dimension, since, as he argues, Genesis is a historical Bible book, like the books of Samuel and Kings, and not a Bible book which is narrated figuratively, like the Song of Songs: non genere locutionis figuratarum rerum ... sed omnino gestarum est. ${ }^{8}$ In Retractationes 2,24,2 he pointedly summarized that he does not intend an allegorical (secundum allegoricas significationes) but literal (secundum rerum gestarum proprietatem) reading. ${ }^{9}$ The distinction between figurate and proprie is a refrain in the first part of Book 8. Some examples of this distinction follow, first the literal and second the prophetic significance (the latter indicated as sacramentum or signum): Adam was both a historical person, of flesh and blood, and the formatype - of Christ. ${ }^{10}$ The tree of life was a physical organism, but also represents divine Wisdom and Christ. ${ }^{11}$ The tree of knowledge of discerning good and evil was also real, and at the same time symbolizes mankind's fall. ${ }^{12}$ Augustine explains that the four rivers of Paradise were not just metaphors, but real rivers (explaining that the Biblical names Gihon and Pishon were changed respectively into Nile and Ganges, and by positing that these two together with the Tigris and the Euphrates have one source in Paradise through underground channels $).{ }^{13}$ He does not give us a clue how these four rivers should be understood figuratively - for instance, by hypothetically comparing them with the four cardinal virtues. In the remaining two-thirds of Book Eight, Augustine actually does not deal with the literal significance of the discussed passages of Genesis 2 anymore.

Interesting to observe is that Augustine explicitly takes distance from his prior attempt to comment on the book of Genesis in De Genesi aduersus

\footnotetext{
8 Augustinus, Gn. litt. 8,1,2 (229,22-24 Z.).

9 Augustinus, retr. 2,24 (CCSL 57, 109,7-8 Mutzenbecher).

10 Augustinus, Gn. litt. 8,1,1 (229,9-21 Z.).

11 Augustinus, Gn. litt. 8,4,8 (235,12-237,2 Z.).

12 Augustinus, Gn. litt. 8,6,12 (239,15-240,14 Z.).

13 Augustinus, Gn. litt. 8,7,13-14 (240,15-242,13 Z.).
} 
Manicheos, which he concisely quotes. ${ }^{14}$ In the second book of De Genesi aduersus Manicheos he interprets the Paradise account univocally in a figurative/ allegorical way. In De Genesi ad litteram Augustine admits that he, in his prior defense of the book of Genesis against its literal rejection by the Manicheans, too rapidly took recourse to figurative hermeneutics, without realizing yet that every aspect of this book should also be taken literally. Yoon Kyung Kim studied the transition of the allegorical De Genesi aduersus Manicheos to the so-called literal De Genesi ad litteram, evidently with particular attention for Book 8, in her dissertation, published in 2006. ${ }^{15}$ According to her, two evolutions in Augustine's mind shaped that transition: a different approach to history and to (the historicity of) the Bible. De Genesi aduersus Manicheos shows that Augustine considered history not as a factual account, but rather as a narrative or a parable. Studying history thus does not mean reconstructing real facts, but disclosing its enigmas and riddles. „In fact, his understanding of history at that time excludes a literal meaning of the text. Or, at least a literal meaning is not meaningful in interpreting the text in terms of history."16 Hence he perceives the Bible, and Genesis in particular, not as a historical source, to be taken literally, but as a prophecy, to be decoded figuratively. De Genesi ad litteram clearly distinguishes history from literary genres such as allegory. Augustine understands history as a factual account of what occurred in the past. Hence a historical book like Genesis should, in a first instance, be consulted as a historical report. As such, a literal approach is identical to a historical approach. For this reason, Augustine stresses at the beginning of Book 8 that the history of the world and mankind did not start after the Fall, but with God's creation, thus making the Paradise account subject of historical research. Augustine's notion of history in De Genesi ad litteram „as a faithful account of what actually happened makes him interpret the creation stories in a properly literal sense. And his literal interpretation makes it clear that history began with God's creation."17

\subsection{Second how: Vnde malum?}

One of the issues that led Augustine to break away from Manichaeism, if we keep in mind the Nebridian conundrum, was the question of evil: where does it originate from, what is its essence, how is it related to God and goodness,

\footnotetext{
14 Augustine cites Gn. adu. Man 2,3 (CSEL 91, 120,11-121,25 Weber) in Gn. litt. 8,2,5 (232,26233,18 Z.).

15 Yoon Kyung Kim, Augustine's Changing Interpretations of Genesis 1-3: From 'De Genesi contra Manichaeos' to ,De Genesi ad litteram'(Lewiston, 2006).

16 Kim, Augustine's Changing Interpretations of Genesis 1-3 (see note 15), 100.

17 Kim, Augustine's Changing Interpretations of Genesis 1-3 (see note 15), 101.
} 
who is finally accountable? The concept of the lignum scientiae boni et mali provides Augustine with an occasion to reflect upon these questions the two times the tree is mentioned in the passage of Genesis under consideration in Book 8. For Augustine's synechdochic use of lignum as synonym for arbor - in this case caused by the Latin translation of Genesis -, we refer to the respective entries of Alfons Weische and Gregor Staab in the Augustinus-Lexikon. ${ }^{18}$

The first time the tree is mentioned, commenting upon all trees in Paradise (Genesis 2,9), Augustine stresses that this tree has both a literal and figurative dimension. ${ }^{19}$ The tree itself, created good by God, is not evil, but received its name as a symbol of man's future transgression: disobedience. The second time the tree is mentioned - the command given to Adam in Genesis 2,16-17 to refrain from eating from it ${ }^{20}$ - Augustine constructs a threefold scheme of what later on will be called a typical Augustinian Theodicy: evil's essence, our experience of it, the possibility of knowing evil through its contrary, or rather through its absence. The links with the plotinian/neo-platonic priuatio boni doctrine are obvious.

The essence of evil is, at first instance, not to be looked for on an ontological level. Augustine's exposition of evil moves from the moral plane to an ontological underpinning. There is nothing evil in the tree itself. As an anti-manichaean slogan, Augustine stresses that nowhere is a natura mali to be found. Neither the forbidden object - the tree -, nor the one issuing the prohibition - God -, are evil, only the transgressor is. What, then, is evil? The answer is simple: sola inobedientia. ${ }^{21}$ The only reason for Adam's sin is to escape from God's rule. The sole motivation for this transgression was the act of transgressing itself. This is how Hannah Arendt would define "radical evil.“22 The moral essence of evil - mankind's transgression - moreover has a double ontological basis. First, disobedience reverses the order in creation, expresses mankind's desire to overrule God, while mankind was originally created rather to serve God. Here we see Augustine being in favor of a sort of natural law. The virtue of obedience thus is not about following commands simply in virtue of them being commands - which would mean that God's command was arbitrarily -, but rather about obeying the natural order which flows from God and creation. By preserving this, one preserves oneself. Augustine adds, that changeable goods

18 A. Weische, „Arbor,“ Augustinus-Lexikon 1 (1986-1994): 433-442; G. Staab, „Lignum,“ Augustinus-Lexikon 3 (2004-2010): 988-992.

19 Augustinus, Gn. litt. 8,6,12 (239,15-240,14 Z.).
20 Augustinus, Gn. litt. 8,13,28-17,36 (251,1-257,17 Z.)

21 Augustinus, Gn. litt. 8,13,29 (251,15 Z.).

22 Hannah Arendt, The Origins of Totalitarianism (New York, 1951); eadem, Eichmann in Jerusalem (Chicago, 1963). 
become even better when they love and serve with their own rational will the unchangeable good. It is thus in mankind's own interest to obey the original commandment. The cause of mankind's insubordination and disobedience is the wish to perversely imitate God, otherwise put, pride - the root of all evil, ${ }^{23}$ Augustine's doctrine of original sin in nucleo. Second, also concisely, Augustine defines evil as priuatio boni: Neque enim ulla natura malum est, sed amissio boni hoc nomen accepit. ${ }^{24}$

We find an almost identical Theodicy in Enarratio in Psalmum 70, condensed in the following sentence: „This is why the tree was called the tree of knowledge, the tree that gave discernment between good and evil. It was so called not because such things dangled from it like fruit, but because whatever species of tree it was, and whatever kind of fruit it bore, persons who refused to discern good from evil on the basis of God's commandment would find out the difference from experience, for by touching what had been forbidden them they would discover only their punishment (hurt, sic). ${ }^{25}$

Since evil thus is not a nature per se, Adam could only learn of its existence through experience, by committing evil. Once Augustine formulates this statement, he realizes he has a huge Christological problem. If it is true that we can only know evil by committing it, how did Christ come to know evil - Christ who was without sin (as the opposite of Adam - Augustine quotes Romans 5,19 and 1 Corinthians 15,22) and thus could not know evil by actually doing it. Augustine now distinguishes two ways of knowing evil: by experience, and through its contrary: the will to not lose the good. Just as nature avoids the loss of what it has, even without experiencing that loss, and, as mankind wants to preserve life, without having experienced death (for that reason Adam could only be convinced to sin in Paradise after having been guaranteed this would not result in death), so too evil can be understood by our desire to preserve the good. Hence we know evil, which is a synonym for losing the good we have, by its contrary, our most intimate desire to preserve the good. Hence, in these few pages we find in nuce the four dimensions Herman J. Häring distinguishes

23 Augustinus, Gn. litt. 8,14,31 (252,23-24 Z.): id est superbiae et contumaciae, peruersae imitationis Dei et noxiae libertatis; in Book 11,31,41 (365,11 Z.) he calls this disobedience: audax curiositas.

24 Augustinus, Gn. litt. 8,14,31 (252,27-253,1 Z.).

25 Augustinus, En. Ps. 70,2,7 (CCSL 39, 966,33-38 Dekkers/Fraipont; trans. Maria Boulding, Expositions of the Psalms [51-72] [The Works of Saint Augustine 3,17; New York, 2001], 445): Ideo arbor illa appellata est scientiae dignoscendi boni et mali, non quia inde talia quasi poma pendebant; sed quidquid esset arbor illa, cuiuslibet pomi, cuiuslibet fructus esset, ideo sic uocata est, quia homo qui nollet bonum a malo discernere per praeceptum, discreturus erat per experimentum, ut tangendo uetitum, inueniret supplicium. 
in Augustine's concept of malum: priuatio boni, ordering principle, personal sin, Adam's universal sin. Augustine's reflections on evil, caused by the tree of moral knowledge, lay the foundation for the doctrine of original sin he deploys in the following Books 10-11. ${ }^{26}$

\subsection{Third how: Quomodo ista locutus sit Deus?}

As indicated above in the general overview, Augustine raises the question of the mode of God's speaking to Adam at two junctures in Book 8. These two statements demand closer scrutiny - not least of all, because the question Augustine formulates remains initially unanswered, and he waits several paragraphs to take up the question again and to answer it succinctly.

How does God address Adam, when offering him the trees in Paradise, or when forbidding him to eat from one tree, and threatening him with death if he did not obey the latter interdiction (Genesis 2,16-17)? Augustine incidentally gave the answer away at the beginning of Book 8 , when he stated that „what God said without any time-measured sounds could only be conveyed to human beings through such sounds in time."27 According to Augustine's first answer (\$18), when taking a stroll in Paradise with Adam (Genesis 3,8), God spoke with Adam in a physical form, just as God would later speak to the Patriarchs. The possibility that God addressed Adam's mind directly and inwardly, without a bodily sound or the likeness thereof, is simply rejected by Augustine. Augustine formulates his first answer quite carefully. Concerning the option that God inwardly directs Adam's intelligence, he writes non sic existimo primo homini locutum Deum; about God's physical voice, he writes talia quippe scriptura narrat, ut potius credamus. ${ }^{28}$ Whether this divine-physical communication proceeded through the mediation of a creature or by God directly, is not (yet) stipulated.

Augustine returns to this question at the very end of Book $8 .^{29}$ He starts by apophatically observing that we actually are not able to fully grasp how God spoke to Adam. ${ }^{30}$ This observation does not hinder Augustine from trying to find an answer to the question posed. He sees two possibilities. Either

26 H.J. Häring, „Malum,“ Augustinus-Lexikon 3 (2004-2010): 1111-1121.

27 Augustinus, Gn. litt. 8,3,7 (235,3-4 Z.; trans. Edmund Hill, On Genesis [The Works of Saint Augustine 1,13; New York, 2002], 350): dici autem hominibus, quid sine temporalibus sonis Deus dixerit, nonnisi per temporales sonos potuit.

28 Augustinus, Gn. litt. 8,18,37 (257,26-258,1 Z.).

29 Augustinus, Gn. litt. 8,27,49-50 (265,23-267,18 Z.).

30 Augustinus, Gn. litt. 8,27,49 (266,2-3 Z.): si modum quaerimus, quomodo ista locutus sit Deus, modus quidem ipse a nobis proprie conprehendi non potest. 
Adam was endowed with such spiritual capacities, that God - per suam substantiam $^{31}$ (speaking per suam substantiam is limited to God's creation act and his enlightening of spiritual beings) - directly enlightened Adam's mind. Such an interlocution would be identical to God's communication with the angels. Either Adam was not able to grasp God's speech directly, and was in need of the mediation by a creature - be it a spiritual one (offering the likeness of bodily things in a dream or ecstasy, or angels), or else Adam grasped God's speech as a bodily vocal appearance (appealing to the senses of the body, making sounds uoces ... uocum signis). ${ }^{32}$ While in his earlier anti-Manichean Genesis commentary Augustine believes in a direct (,unclouded') interior communication between God and mankind's intellect prior to the Fall, ${ }^{33}$ he here affirms that only the second option is the correct one: „nobody who has the least sense of the Catholic faith will have any doubt at all that this was done through some creature subject to God, and not through his own substance."34 Sabine MacCormack, in her Saint Augustine Lecture of 2007, seems to have overlooked this assertion by Augustine, when she concludes: „Yet, notwithstanding the Fall, ,holy souls' in the here and now were able to hear the voice of God directly and without mediation - which amounted to Augustine affirming the reality of his conversations with God in the Confessions, but now in the more impersonal, more formal language of De Genesi ad litteram. "35 Furthermore, at this juncture, Augustine excludes the possibility of an experience like the one he himself enjoyed during the so-called Ostia-ecstasy, at least according to his own description in Confessiones 11,23-25.

Augustine underpins his choice for a mediated divine speech with a Christological argument. Referring to 1 Timothy 6,16 and Philippians 2,7, he

31 Augustinus, Gn. litt. 8,27,49 (266,4 Z.).

32 Augustinus, Gn. litt. 8,27,49.50 (266,15; 267,3 Z.).

33 Augustinus, Gn. adu. Man 2,5 (CSEL 91, 123,18-124,23 Weber; trans. Roland J. Teske, St. Augustine on Genesis [The Fathers of the Church; 84; Washington, 1999], 99): ante peccatum uero cum uiride agri et pabulum [Gn 2,5] fecisset Deus, quo nomine inuisibilem creaturam significari diximus, irrigabat eam fonte interiore loquens in intellectu eius, ut non extrinsecus uerba exciperet tamquam de supradictis nubibus pluuiam, sed fonte suo, hoc est de intimis suis manante ueritate satiaretur.

„But before sin God had made the green of the field and food, and we said that this expression signified the invisible creature. God watered it by an interior spring, speaking to its intellect, so that it did not receive words from the outside, as rain from the aforementioned clouds. Rather it was satisfied from its own spring, that is, by the truth flowing from its interior."

34 Augustinus, Gn. litt. 8,27,50 (267,5-7 Z.; trans. Hill, On Genesis [see note 27], 375): quia non per ipsam Dei substantiam, sed per subditam ei creaturam factum est, nullo modo dubitat, quifidem catholicam sapit.

Sabine MacCormack, „Augustine Reads Genesis,“ Augustinian Studies 39 (2008): (5-47) 46. 
asserts that Christ did not take a body, did not become visible before the moment of his incarnation. Tackling "heretics," who assert the visibility of Christ before his incarnation, he thus implies that a physical expression of God before the incarnation is not feasible. Augustine takes a similar position again with great care - about God's mediated speech in De Trinitate 2,10,17-18, even seeming to allow that the Son or the Trinity as a whole spoke to Adam. Afterward, he continues De Trinitate 2 by a comparison of God's conversational stroll in Paradise with how He later addressed the Patriarchs. Identical to his treatment in Book 8 of De Genesi ad litteram, Augustine rejects the possibility of an inward, divine enlightenment of Adam's intellect, contending that God addressed Adam through mediation of an unspecified creature - perhaps through a dream/vision or an angel.

\subsection{Fourth how: Opus bipartitum diuinae prouidentiae?}

Virgilio Pacioni argues that we need to read De Genesi ad litteram 8 to understand the twofold development in Augustine's interest in providence. ${ }^{36}$ First, Augustine tries to grasp the philosophical essence of providence. De ordine $1,1,1-2$ posits that the universe is neither the result of chance, nor ruled by an immanent order. It is ordered well by the iudicium of a transcendent and personal God. De libero arbitrio 2,17,45 argues that since God is the immutable form in which all that exists, subsists and develops according to its particular form, He is the providence of all that exists. Second, he reflects, in a theological way, on the operative force of providence. De Genesi ad litteram describes both the intrinsic creative operation of God's goodness and the extrinsic ordering by his justice. De uera religione 7,12-13 stresses that providence personally interacts, through prophecies and in history. De ciuitate Dei 3,1; 21,13 concludes that human affairs are directed by providence aimed at establishing the heavenly city.

In paragraphs 19-26 Augustine interrupts his line by line commentary, and devotes his full attention to the metaphysical doctrine of God's twofold providence. The first apparent explanation for this shift is that Augustine wants to elaborate an issue he already raised - in passing - two times in preceding paragraphs. One could say that the topic of God's double operative providence is a leitmotiv in Book 8. Augustine perceives a parallel between mankind's working in paradise (Genesis 2,15) and, on a cosmic scale, the gemina operatio

36 Virgilio Pacioni, „Providence," in Augustine through the Ages: An encyclopedia (ed. Allan Fitzgerald; Grand Rapids, 1999): 686-688. 
prouidentiae. ${ }^{37}$ Providence functions partim naturalis, partim uoluntaria, ${ }^{38}$ comparable with the activities of body and soul in the human person. At this juncture Augustine summarizes this twin operation of providence comparable to what today would be labeled as nature and culture. When Augustine alternatively suggests that God is „working and guarding“ mankind, Augustine asserts that the twin operation of God's providence works and guards mankind's well-being. ${ }^{39}$

The second reason for expounding on God's providence at this point of the argument is clearly stated at the beginning of $§ 19$. Augustine here links that explanation with the previous section on God's communication: in order to help his readers comprehend how God spoke to Adam, and to avoid their possible misapprehension of God's substance, Augustine sets out to explain the opus bipartitum of divine providence. ${ }^{40}$ When Augustine subsequently elucidates the nature of God's providence, it will become clear for the attentive reader that a direct vocal interlocution or inward illumination are by definition impossible. Understanding the nature of God's providential working, in turn helps one to understand God's substance, which again enables to gain insight in the way God communicated with Adam in paradise. Augustine's metaphysical excursus about providence thus results from Augustine's exegesis of the passages in Genesis 2 dealing with God's speaking to Adam. In a somewhat associative way - it takes a very careful reading to make the following reconstruction based on De Genesi ad litteram - he sees this bipartite characteristic of providence on three - interwoven - levels: (1) temporal or spatial, (2) natural or voluntary, (3) internal or external.

(1) Augustine starts by laying an ontological foundation. God is not to be located in any space - finite or infinite -, nor is He subject to time - finite or infinite. God created spiritual and corporeal realities. Since the spiritual can only be altered by time, and since the bodily creations are changed by time and place, the former has precedence over the latter. Consequently, divine providence moves the human soul through time and the human body through time and space.

(2) After thus distinguishing God's temporal interaction with the soul/spiritual beings from God's temporal and spatial directing of the human body/

37 Augustinus, Gn. litt. 8,9,17 (244,2 Z.).

While Augustine here refers to the said parallel, in 9,15,26-18,35 (286,18-293,27 Z.) he will explain the fundamental three-fold difference between the work of God, of angels, and of mankind.

38 Augustinus, Gn. litt. 8,9,17 (244,2-3 Z.).

39 Augustinus, Gn. litt. 8,12,25 (249,10-22 Z.).

40 Augustinus, Gn. litt. 8,19,38-26,48 (258,6-265,22 Z.). 
corporeal creatures, Augustine - according to a parallel structure - shows that providence works differently on the level of natures and wills. „So then, God's providence rules and administers the whole of creation, both natures and wills; natures so that they may simply be, wills on the other hand so that neither the good ones may be unfruitful nor the bad ones go unpunished." ${ }^{41} \mathrm{On}$ the level of natures, we see the creative operation of providence, the result of God's goodness; on the level of the wills, providence functions in an ordering way, as expression of God's omnipotence: naturas creans bonitate, uoluntates ordinans potestate. ${ }^{42}$

(3) The bodily creation receives both internal and external assistance from God (adiuuator/extrinsecus ... intrinsecus). ${ }^{43}$ Bodily creatures are inwardly directed by God by the fact they are created as they are by God. From God they receive their being (their existence in general and their specific nature). Externally they are helped by God so they could be in a better shape (food, agriculture, medicine, adornment). God provides this external help through wills (which He moves in time) that are subject to Him, and through bodies (in time and space) subjected to Him. The created spiritual natures only receive non-bodily internal divine aid, that is, they are instantly enlightened by God (and not through external tools like writings, spoken words, dreams or visions). At this juncture Augustine restricts the category of spiritual natures to the holy angels, and probably deliberately, does not mention the human soul (because, as we already discussed, he will in the next paragraph reject the thesis that God inwardly illuminates the human mind). Augustine adds that one could also, albeit not in strictu sensu, say angels receive external assistance by the fact they enjoy their mutual company, and by the gratitude they feel in seeing the totality of God's creation.

We should add that the providential ordering of the human wills does not destroy free will. Augustine suggests that providence intervenes after the human free decision is taken, as we read that his ordering providence rewards good wills and punishes bad ones. Moreover, it is suggested that God's providential interference with human wills proceeds externally, and not inwardly. Differently put, following the evolution studied by Lenka Karfíková in Augustine's understanding of the relationship between human will and divine grace, ${ }^{44}$ we did not yet reach his anti-Pelagian conceptualization thereof (esp.

41 Augustinus, Gn. litt. 8,23,44 (262,17-20 Z.; trans. Hill, On Genesis [see note 27], 371): ergo Dei prouidentia regens atque administrans uniuersam creaturam, et naturas et uoluntates, naturas, ut sint, uoluntates autem, ut nec infructuosae bonae nec inpunitae malae sint.

42 Augustinus, Gn. litt. 8,23,44 (262,5-7 Z.).

43 Augustinus, Gn. litt. 8,25,46 (263,17-19 Z.).

44 Lenka Karfíková, Grace and the Will According to Augustine (VCS 115; Leiden, 2012). 
the notion that God ,prepares' the human will). Along the same lines, we can observe that Augustine approaches providence here solely from the positive side, the later anti-Pelagian emphasis that grace/predestination is God's positive answer to mankind's negative situation - i.e. sin and man's incapability to escape from it - is not thematized here yet.

\section{Conclusion}

A potpourri gathers a blend of many aromatic flowers. De Genesi ad litteram 8 has proven to be a similar mixture, and thus should be considered neither as a unified coherent treatise, nor as a systematic comprehensive verse by verse biblical commentary. However, at the same time, Book Eight contains some representative pieces of dried flowers, almost mini-treatises of important elements found throughout Augustine's oeuvre. In point of fact, these key components intimate significant steps in the interior development of his understanding of the Bible, the world, and the relationship between man and God.

Augustine addresses the issue of God's communication to Adam. God communicated with Adam by using a mediator. His answer to the question about God's timeless speech in our time-bound reality in De Genesi ad litteram thus foreshadows his more systematic and elaborate reflection upon this question in De Trinitate 2.

Augustine pleads for a literal reading of the book of Genesis, in this case of Genesis 2,8-17. In this light, he intends to offer an historical account of the creation narrative embedded in the broader sequence of the garden episode. This literal or historical form of exegesis resulted in a lengthy exposition on God's providence, in which he touches upon the metaphysical order with which God bestowed his physical creation. As John J. O'Meara somewhat misleadingly remarked during his Saint Augustine Lecture at Villanova in 1977: „One must not take Augustine's ,literally' in his title Genesis Understood Literally quite ,literally." 45 More recently, and somewhat more aptly, Roland Teske described De Genesi ad litteram as: „more a theological reflection on the Scripture in the light of the faith, than a straightforward exegesis of the text." 46 According to a common sense meaning of ,literal,' Augustine indeed seems in book 8 less interested in a verse by verse exegesis of Genesis 2,8-17 and the ,historical facts this passage narrates (creation, Paradise, Adam and his disobedience). Instead,

45 John J. O'Meara, The Creation of Man in St. Augustine's De Genesi ad litteram (Saint Augustine lecture series 1977; Villanova, 1980), 16.

46 R.J. Teske, „De Genesi ad litteram,“ Augustinus-Lexikon 3 (2004-2010): (113-126) 117. 
he ponders primarily about the Creator's providence, the whole of the created Cosmos, Christ and his grace: each of which, however, integrally belong to (salvation-)history, according to Augustine. As such, creation and providence are intrinsically interwoven, and Augustine's meditation about both expresses his intention to historically (secundum historiam), ${ }^{47}$ thus literally (ad litteram), understand the words of the first book of the Bible.

47 Cf. Augustinus, Gn. adu. Man 2,3 (120,8-10 W.). 
